\title{
Cross-frontal distribution of inorganic nutrients and chlorophyll-a on the Patagonian Continental Shelf of Argentina during summer and fall
}

\author{
Distribución de nutrientes inorgánicos y clorofila- $a$ a través de los frentes de la Plataforma \\ Continental Patagónica Argentina durante verano y otoño \\ Flavio E. Paparazzoㄹ, Laura Bianucci², Irene R. Schloss ${ }^{3}$, Gastón O. Almandoz ${ }^{4}$, \\ Miriam Solís ${ }^{1}$ and José Luis Esteves ${ }^{1}$ \\ ${ }^{1}$ Centro Nacional Patagónico (CENPAT-CONICET), Bvd. Brown 3000 (9120), Puerto Madryn, Chubut, Argentina \\ ${ }^{2}$ School of Earth and Ocean Sciences, University of Victoria, 3800 Finnerty Road (Ring Road), \\ Victoria, BC Canada V8P 5 C2 \\ ${ }^{3}$ Instituto Antártico Argentino (IAA), Cerrito 1248 (C1010AAZ), Buenos Aires, \\ Argentina, and CONICET, Argentina \\ ${ }^{4}$ Facultad de Ciencias Naturales y Museo, Universidad Nacional de La Plata, \\ Paseo del Bosque s/n, (1900) La Plata, Argentina, and CONICET, Argentina \\ paparazzo@cenpat.edu.ar
}

\begin{abstract}
Resumen.- Datos oceanográficos recolectados durante 2001-2003 en la Plataforma Continental Patagónica Argentina fueron analizados para estudiar las principales características químicas en esta gran plataforma. Se presenta la variación de los nutrientes inorgánicos y de la clorofila- $a$ a una distancia de 40 a $60 \mathrm{~km}$ de la costa. El nitrato es el nutriente limitante en la región y está negativamente correlacionado con la clorofila- $a$. Todas las variables presentan variaciones localizadas en verano, las cuales pueden ser relacionadas con los frentes de marea a través de la comparación de nuestros datos con el parámetro crítico de estabilidad de Simpson $\left(50 \mathrm{~J} \mathrm{~m}^{-3}\right)$. En otoño, la concentración de nutrientes en la plataforma continental fue más uniforme y generalmente mayor que en verano debido a la disrupción de dichos frentes.
\end{abstract}

Palabras clave: Nutrientes (minerales), frentes de marea, surgencias, plataformas continentales, biogeoquímica, Atlántico SO

\section{Introduction}

The Continental Shelf of the South-Western Atlantic Ocean is one of the largest in the world and is considered a Large Marine Ecosystem (LME) (Bisbal 1995). It contains rich and productive habitats, which sustain fisheries and a wide and diverse community of top predators that feed on and breed in its seas. The region south of $40^{\circ} \mathrm{S}$ is usually known as Patagonian Continental Shelf of Argentina (PCSA). It has one of the strongest tidal regimes of the world, which generates energetic currents (Piola \& Rivas 1997, Rivas 1997); many shallow coastal areas of the shelf are mixed by tidal energy

\begin{abstract}
Oceanographic data collected during 2001-2003 on the Patagonian Continental Shelf of Argentina were analyzed in order to study the main chemical features of this large shelf. The variation of inorganic nutrients and chlorophyll- $a$ during summer and fall in an area within 40 to $60 \mathrm{~km}$ from the coast are presented. Nitrate is the limiting nutrient in the region and is negatively correlated to chlorophyll-a. All variables show localized variations in summer, which can be related to tidal fronts through the comparison of our data with the critical Simpson parameter of stability $\left(50 \mathrm{~J} \mathrm{~m}^{-3}\right)$. In fall, nutrient concentrations on the continental shelf were more uniform and generally higher than in summer due to the disruption of these fronts.
\end{abstract}

Key words: Nutrients (mineral), tidal fronts, upwelling, continental shelves, biogeochemistry, SW Atlantic

throughout the year. During the warm season there are sharp gradients in most properties between these well homogenized coastal waters and the stratified mid-shelf waters (Carreto et al. 1986, Acha et al. 2004, Bianchi et al. 2005, Romero et al. 2006, among others). These fronts are usually called 'tidal fronts' because tides are the key mechanism for shallow water homogenization, as seen in numerical models (Glorioso \& Flather 1997, Palma et al. 2004). During the cold season, stratification is destroyed over the mid-shelf by convection and wind mixing, and tidal fronts disappear. Several authors have pointed out the importance of fronts in primary production, as well as in trophic structure (Simpson 1981, 
Joiris 1996, Koen-Alonso et al. 2001, Sponaugle et al. 2002, Flint et al. 2002). Frontal zones allow the presence of the high surface chlorophyll- $a$ concentrations during summer (Rivas et al. 2006), as described in detail by Schloss et al. (2007) for the tidal fronts of Valdés Peninsula $\left(42^{\circ} \mathrm{S}\right)$, San Jorge Gulf (close to $46^{\circ} \mathrm{S}$ ), its southern tip (Blanco Cape) and Grande Bay (close to $52^{\circ} \mathrm{N}$ ). This is mainly because of the pumping of nutrients due to stratification weakening or disruption (Acha et al. 2004). On the PCSA, Romero et al. (2006) found a clear correspondence between regions of large tidal dissipation and satellite-derived chlorophyll- $a$ (chl- $a$ ), suggesting that tidal mixing has a major role in the redistribution of nutrients. Moreover, Rivas (2006) showed that frontal areas cover less than $15 \%$ of the total surface of the PCSA, but contribute with over $23 \%$ of the phytoplankton annual mean biomass.

Various fronts have been detected on the PCSA (Sabatini \& Martos 2002, Glorioso 2002; Acha et al. 2004). These regions are the final destination of different fauna annual migrations, as well as the feeding grounds for numerous marine birds and mammals (Veit 1995, Berrow et al. 2000, Koen-Alonso et al. 2000, Croxall \& Wood 2002). However, the study of these areas of the
PCSA is not only important from a biodiversity point of view. Fisheries represent a social and economic relevant activity and depend on frontal regions for sustainability, as breeding and capture territories of the main target species (Merluccius hubbsi, Pleoticus muelleri, Engraulis anchoita, Zygochlamys patagonica and Illex argentinus) are usually found along frontal zones (Hansen et al. 2001, Aranciaga 2003, Bogazzi et al. 2005).

The zones where tidal fronts are conspicuous in the PCSA are shown in Fig. 1, as described by Bianchi et al. (2005). This figure shows the location of the critical Simpson parameter of vertical stability (Simpson 1981), which is a measure of the mechanical work needed to homogenize the water column. It can be used to estimate the location of tidal fronts by delimiting well-mixed coastal waters from stratified mid-shelf waters. This parameter has been used in several studies in the region (Sabatini \& Martos 2002, Sabatini et al. 2004, Bogazzi et al. 2005). Furthermore, Bianchi et al. (2005) characterized the PCSA in three regions: (1) a coastal zone, up to about $60 \mathrm{~m}$ depth with well-mixed waters; (2) a strongly stratified mid-shelf with mixed layer depths around $200 \mathrm{~m}$; (3) a weakly stratified outer shelf, where stratification decays approaching the shelf break.

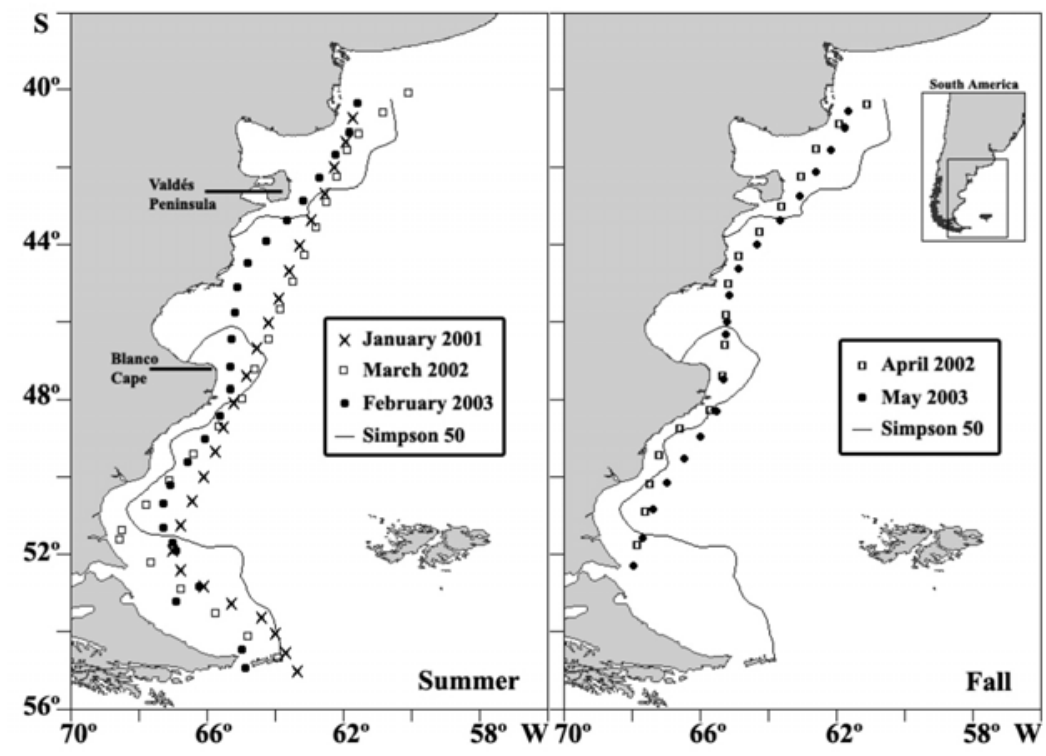

Figure 1

ARGAU transects used in this work (austral summer and fall shown in different plots). The solid line represents the critical Simpson parameter $\left(50 \mathrm{~J} \mathrm{~m}^{-3}\right.$ ) as calculated by Bianchi et al. (2005). The insert map shows the location of the Patagonian Continental Shelf of Argentina

Transectas ARGAU usadas en este trabajo (verano y otoño austral presentados por separado). La línea sólida representa el parámetro de Simpson crítico $\left(50 \mathrm{~J} \mathrm{~m}^{-3}\right)$ tal como fue calculado por Bianchi et al. (2005). El mapa interno muestra la localización de la Plataforma Continental Patagónica Argentina 
No detailed studies of nutrients along the whole extension of the PCSA were done in the last 30 years. Between 1967 and 1970, 18 cruises known as 'Pesquerías' were carried out providing information on the oceanographic features of the Argentine Sea (i.e. Brandhorst \& Castello 1971). Later, the INIDEP (Instituto Nacional de Investigación y Desarrollo Pesquero) and the Naval Hydrography Service performed cruises in some of the different zones of the PCSA (Carreto et al. 1986, Carreto et al. 2007). Recently, during the ARGAU project (French project in Cooperation with ARGentina for the study of the AUstral Atlantic Ocean, Balestrini et al. 2000) several cruises provided a more recent data set to describe this large zone of the South-Western Atlantic. Preliminary data analysis (Paparazzo 2003) showed high nitrate surface concentrations during the entire warm period (spring and summer). In the frame of this project, we analyzed seasonal chemical features of near-surface waters in the PCSA during 2001-2003. The goal of this work was describe and analyze the mineral nutrient and chl- $a$ distributions of the coastal PCSA (40 to $60 \mathrm{~km}$ from the coast), with a focus on the connection between these distributions and tidal fronts. Studies of this kind will contribute to the conservation of this regional sea, providing an update of its biochemical state and improving the understanding of its main characteristics.

\section{Material and methods}

Samples for nutrient analysis were collected onboard the Argentinean icebreaker 'Almirante Irizar' during austral summer of 2001 and summer and fall of 2002 and 2003 in the PCSA. They were collected at 3-hour intervals from a continuous system with an intake installed 9 m deep on the keel of the ship. Between 2 and $4 \mathrm{~L}$ of water were filtered onto pre-combusted Whatman GF/F filters and stored in $250 \mathrm{~mL}$ polyethylene bottles for nutrient analysis, while the filters were used for the chl- $a$ determination. Both filtered water and filters were kept at $-20^{\circ} \mathrm{C}$ until analysis. Duplicate samples of nitrate and phosphate were analyzed at the Centro Nacional Patagónico (CENPAT), following Strickland \& Parsons (1972). In the case of nitrate, the method was modified to perform the analysis with a Technicon II autoanalyzer. Reactive silicate was measured following the method suggested in Technicon (1977¹). Chlorophyll- $a$ was analyzed at the Instituto Antártico Argentino using Strickland \& Parsons (1972) methods. In addition, in 2003 qualitative net (20 $\mu \mathrm{m}$ mesh) and quantitative samples were collected directly from the pumping system

\footnotetext{
${ }^{1}$ Technicon. 1977. Technicon Ind. Method 186-72/W: Silicate in water and seawater. Technicon Ind. Systems, Tarrytown, N.Y.
}

for phytoplankton analyses. All samples were fixed with acidic Lugol's iodine solution and kept in dark conditions at room temperature until analysis at the phycology laboratory of La Plata University. Net samples were observed by light microscopy both in water mounts and in oxidized material mounted in Naphrax with a phase contrast Wild M20 microscope, and were additionally examined by scanning electron microscopy (Jeol JSM6360 LV, at the SEM service, Museo de La Plata). Cells were enumerated with an Iroscope SI-PH inverted microscope according to the procedures described by Utermöhl (1958). Identification of individual cells was performed to the lowest possible taxonomical level (i.e. most diatoms were identified to species level whereas many phytoflagellates were identified to class level). Since flagellates generally lose their flagella by the addition of fixatives, unidentified small $(\leq 5 \mu \mathrm{m})$ phytoflagellates and round-shaped organisms with or without flagella were included in a single group as 'small flagellates'. Near sea surface (9 $\mathrm{m}$ depth) temperature data were collected underway and averaged and recorded at 10-minute intervals. For the present work we selected five transects that intersected tidal fronts (see Fig. 1 for summer and fall cruises), i.e. transects usually located between 40-60 km from the coast and within the $100 \mathrm{~m}$ isobath. Out of the 110 selected stations, 74 corresponded to summer (January to March) and 36 to fall (April and May).

The Simpson critical parameter values used in the present work were those calculated by Bianchi et al. (2005). It should be noted that their calculation is not possible with the data from the present study; only surface information is available. Bianchi et al. (2005) computed this parameter with a historical data set and those results are therefore used as a climatological representation of the location of summer fronts.

\section{Results}

\section{Front localization}

Fronts can be distinguished by sharp changes in surface temperature. The weight-averaged temperature gradient $\left({ }^{\circ} \mathrm{C} \mathrm{km}^{-1}\right)$ for each transect has been depicted in Fig. 2.

Gray bars indicate the regions where each transect intersects the critical Simpson parameter $\left(50 \mathrm{~J} \mathrm{~m}^{-3}\right) \pm 20 \%$ (i.e. between 40 and $60 \mathrm{~J} \mathrm{~m}^{-3}$ ). This range is a representation of the frontal zone (region of large property gradients), while the critical Simpson parameter represents the location of the front (i.e. where the largest gradients are found). The sharp in-situ temperature gradients observed in the Fig. 2 is slightly displaced from the location of the front as seen by the Simpson critical 

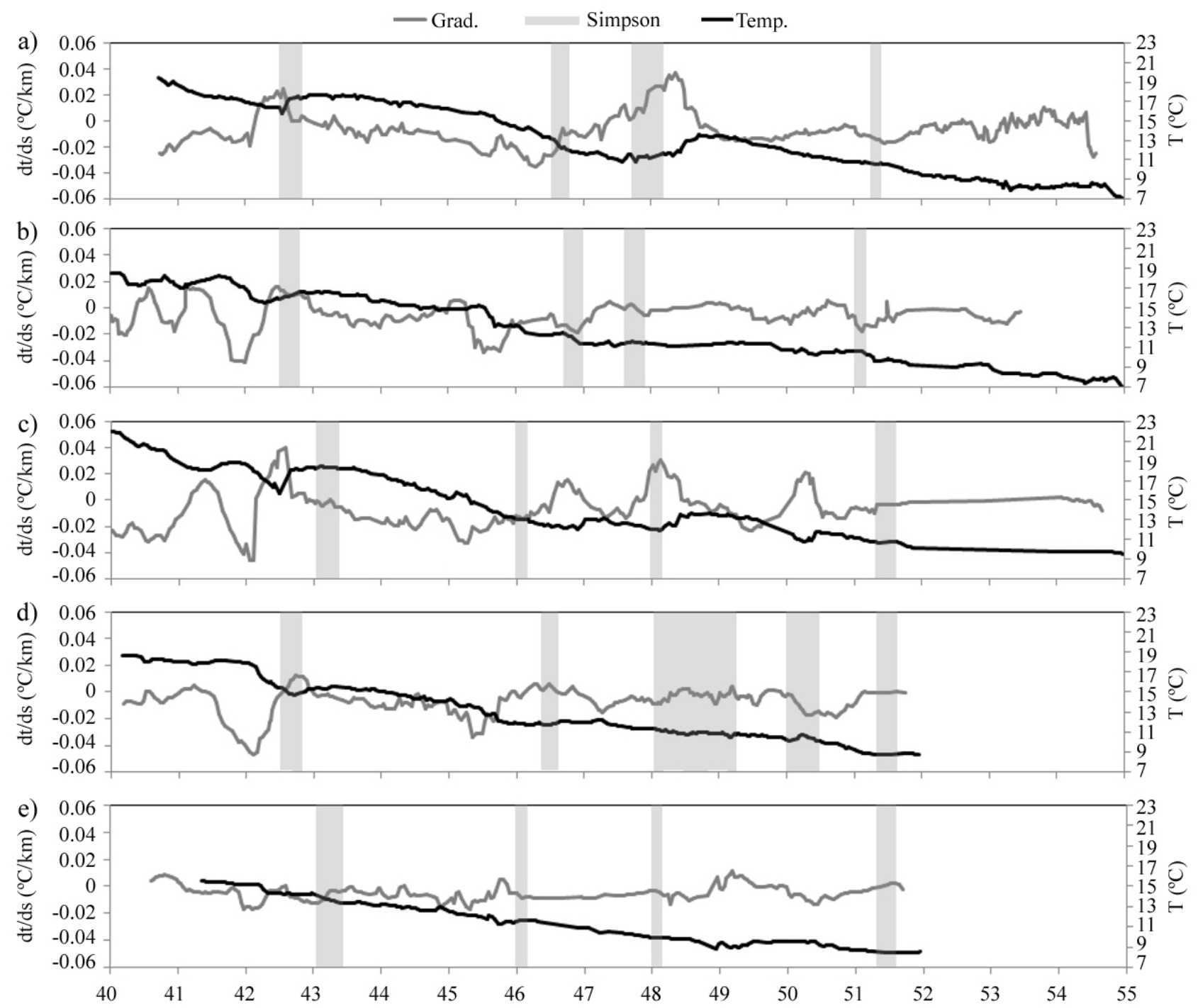

Latitude $\mathrm{S}\left({ }^{\circ}\right)$

Figure 2

Data plotted against latitude for all transects. Panels show temperature and thermal gradient for a) January 2001, b) March 2002, (c) February 2003, d) April 2002 and e) May 2003. Gray bars represents the latitudes at which the transects intersect the regions with Simpson parameter values around $20 \%$ of the critical value (between 40 and $60 \mathrm{~J} \mathrm{~m}^{-3}$ )

Datos ploteados latitudinalmente para todas las transectas. Los paneles muestran las curvas de temperatura y gradiente térmico para a) enero 2001, b) marzo 2002, c) febrero 2003, d) abril 2002 y e) mayo 2003. Las barras grises representan las latitudes en las cuales las transectas interceptan regiones con valores cercanos al 20\% del parámetro de Simpson crítico (entre 40 y $60 \mathrm{~J} \mathrm{~m}^{-3}$ ) 
parameter (especially in fall, when tidal fronts are weaker or destroyed) probably due to the fact that only surface temperature values are available. In addition, note that transects cross the critical Simpson line in several places and with different orientations (Fig. 1), so that fronts are not seen in the exact same way each time. Lastly, transects were performed during different months and years within the same season, while the Simpson values calculated by Bianchi represent a summer climatology.

The first frontal region found in our data was located off Valdés Peninsula (around 42 to $43^{\circ} \mathrm{S}$ ). At these latitudes, summer transects showed sharp changes in thermal gradient (Fig. 2a-c). During fall, the gradient still indicated the presence of a front in April 2002 (Fig. 2d) while it was not as clear in May 2003 (Fig. 2e).

The second frontal region was located near Blanco Cape (between 45.5 and $48^{\circ} \mathrm{S}$ ). A first pronounced thermal gradient around $45.5^{\circ} \mathrm{S}$ was evident both in summer and fall, while a second one around $48^{\circ} \mathrm{S}$ (Fig. 2a-c) was only evident until April (Fig. 2d, e).

The third frontal region extended south of $50^{\circ} \mathrm{S}$. In January 2001 and March 2002 local changes of the temperature gradient denote a front near $51^{\circ} \mathrm{S}$ (Fig. 2a, b). In February 2003 a pronounced peak at $50.5^{\circ} \mathrm{S}$ was found (Fig. 2c). Fall data only reach the $52^{\circ} \mathrm{S}$, limiting our analysis of this front. During April 2002 a maximum was found around $50^{\circ} \mathrm{S}$ as in February 2003 although not as high (Fig. 2d). A second gradient increase was observed at $51.5^{\circ} \mathrm{S}$. Finally, in May 2003 there were no strong variations in the surface temperature gradient in the region (Fig. 2e).

The frontal regions observed here have been previously described (e.g. Romero et al. 2006, Carreto et al. 2007). A chemical (nutrients) and biological (chla) description of each of these fronts based on nearsurface data from five ARGAU alongshore transects follows.

\section{Valdés Peninsula}

Summer. The three summer transects intersected the critical Simpson line around $42.5-43^{\circ} \mathrm{S}$, although at these latitudes, the historical observations available to calculate the stability parameter were scarce, so it does not properly detect the northern limit of the front (see Bianchi et al. 2005). In 2003, the critical Simpson line was found displaced towards the south of the sharp near-surface temperature gradient (Fig. 2). In the other transects, the observed temperature gradients were close to the climatological critical Simpson value. This front was characterized by low near-surface temperature in the homogeneous (northern) side of the front (Fig. 2).
Moreover, the cold side presented similar temperatures in January 2001, March 2002, and February 2003 $\left(\sim 15.7^{\circ} \mathrm{C}\right)$.

Nitrate concentrations in the area were undetectable in 2001 (Fig. 3a). In 2002 and 2003 nitrate maxima (4.1 and $1.7 \mu \mathrm{M}$, respectively) occurred along with minimal temperature; in 2001 phosphate concentrations showed a local maximum north of the front position. In 2002, phosphate maximum was found north of the nitrate peak, while in 2003 (Fig. 3b) both peaks were spatially coincident. In terms of silicate, in 2001 its maximum was displaced north of nitrate maximum. Peak concentrations in 2002 and 2003 (2.9 and 3.4 $\mu \mathrm{M}$ respectively, Fig. 3c) were found along with nitrate maxima. The location of the chl- $a$ maximum varied in the three transects (Fig. 3d). In January 2001, chl- $a$ was low (max. $0.65 \mu \mathrm{g} \mathrm{L}^{-1}$ ) and was found only slightly to the north of the front. This would indicate that there was some nitrate limitation, probably because the system had not yet recovered from the spring bloom. March 2002 shows high chl- $a$ (2.90 $\mu \mathrm{g} \mathrm{L}^{-1}$ ) to the south of the front (stratified waters). In February 2003 the chl- $a$ peak extended from the nitrate maximum to the north (up to $2.03 \mu \mathrm{g} \mathrm{L}^{-1}$ ).

Fall. The two fall transects had similar tracks, but the 2003 cruise was carried out one month later in the season. That was probably why the drop in temperature at the Valdés Peninsula front could be seen in 2002, but was not as well defined during 2003 (Fig. 2). A nitrate concentration peak of $\sim 4 \mu \mathrm{M}$ was observed in both transects (Fig. 4a), suggesting that the front was still evident in both April 2002 and May 2003. Phosphate was relatively high at both sides of the front in April 2002, while it showed a maximum close to the nitrate peak in May 2003 (Fig. 4b). Silicate presented maximum concentrations (Fig. 4c), at the southern edge of the front in 2002 and north of it in 2003.

In April 2002 there was a chl- $a$ maximum $(1.60 \mu \mathrm{g} \mathrm{L}$ ${ }^{1}$ ) at $\sim 41.5^{\circ} \mathrm{S}$ (north of the nutrient maxima as well as north of the front in stratified waters), while a lower peak could be observed to the south $\left(0.89 \mu \mathrm{g} \mathrm{L}^{-1}\right)$, close to $44^{\circ}$ $\mathrm{S}$ (also outside of the homogeneous side of the front). In May 2003 chl-a has two maxima located around the nutrients peaks (Fig. 4d), i.e. in weakly but yet stratified waters: $4.80 \mu \mathrm{g} \mathrm{L} \mathrm{L}^{-1}$ at $\sim 41.5^{\circ} \mathrm{S}$ and $2.90 \mu \mathrm{g} \mathrm{L}^{-1}$ at $\sim 43.5^{\circ}$ $\mathrm{S}$. The northern chl- $a$ maximum was associated with the highest diatom density observed in the whole transect, while the southern peak was due to the presence of a large dinoflagellate (Prorocentrum micans) and cryptomonads (data not shown). Further information on phytoplankton species composition is presented in Almandoz et al. (2007) and Almandoz (2008). 

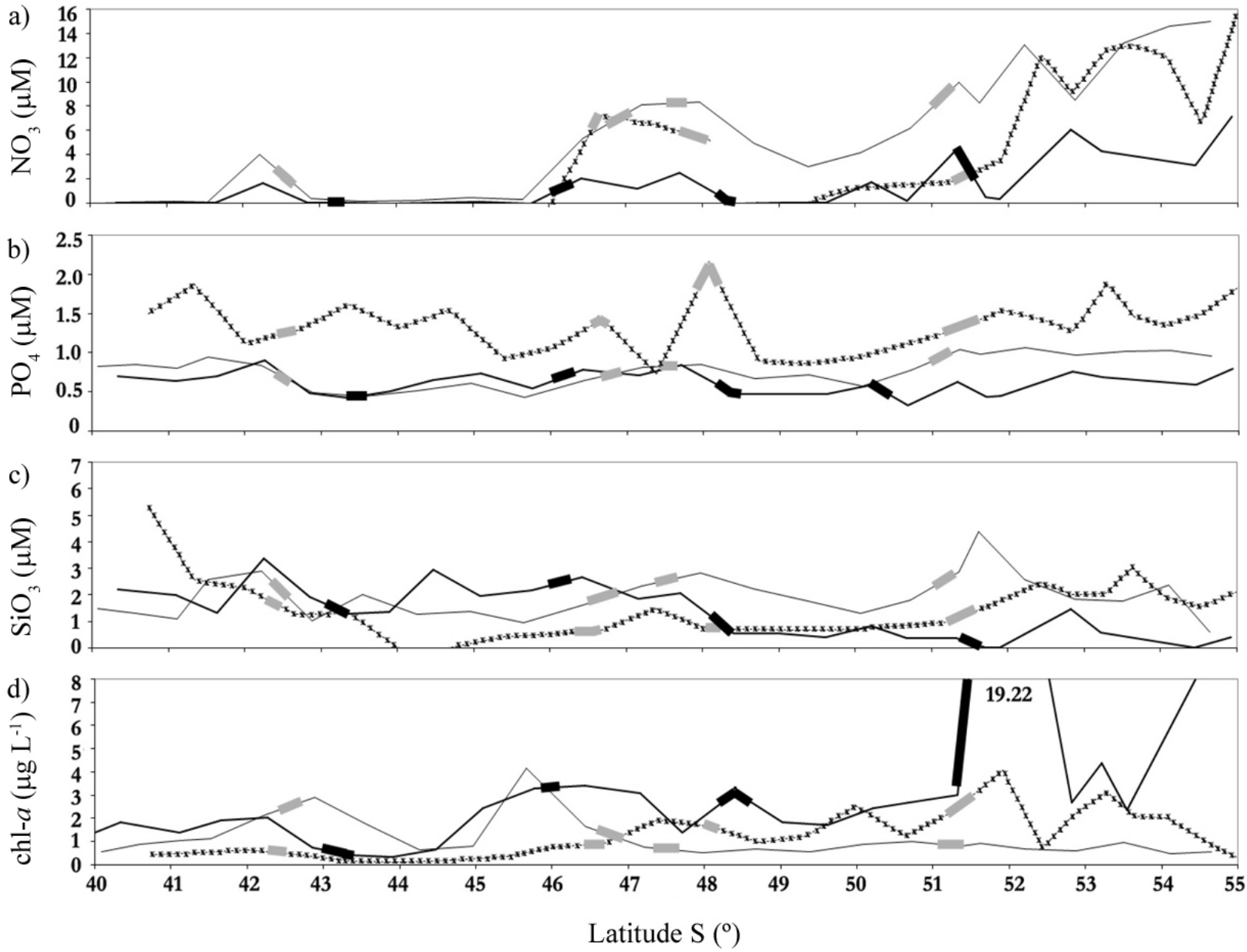

Jan 2001 …..... Mar $2002-$ Feb $2003-$

Figure 3

Variation of a) nitrate, b) phosphate, c) silicate and d) chl-a. along a latitudinal gradient during summer. In each transect and for all variables, lines are thicker where the Simpson value $40-60 \mathrm{~J} \mathrm{~m}^{-3}$ is crossed

Variaciones de a) nitrato, b) fosfato, c) silicato y d) clorofila- $a$ a lo largo de un gradiente latitudinal durante verano. En cada transecta y para cada variable, las líneas se engrosan cuando cruzan el valor de Simpson 40-60 J m 

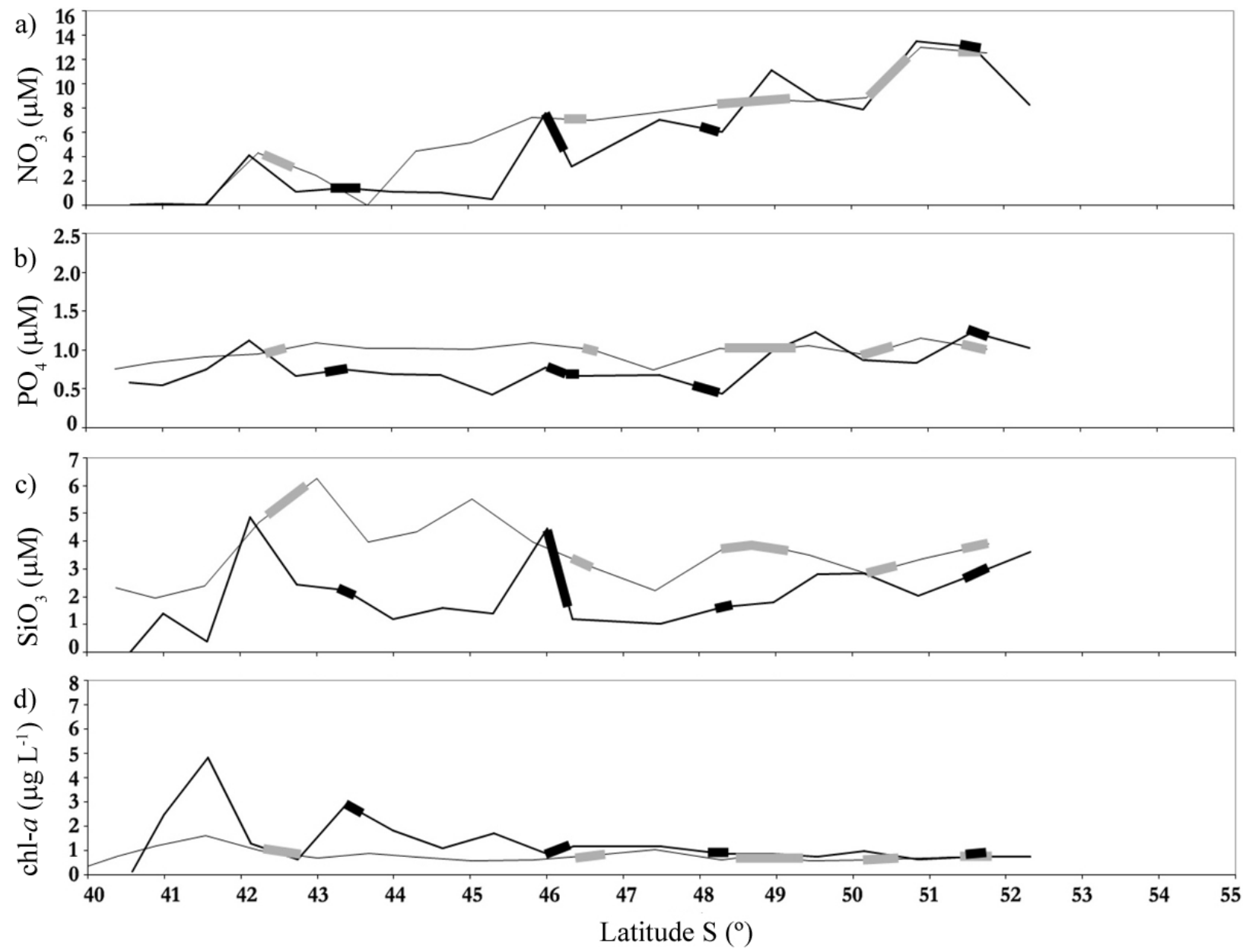

Apr $2002-$ May $2003-$

Figure 4

Variation of a) nitrate, b) phosphate, c) silicate and d) chl-a. along a latitudinal gradient during fall. In each transect and for all variables, lines are thicker where the Simpson value $40-60 \mathrm{~J} \mathrm{~m}^{-3}$ is crossed

Variaciones de a) nitrato, b) fosfato, c) silicato y d) clorofila- $a$ a lo largo de un gradiente latitudinal durante otoño. En cada transecta y para cada variable, las líneas se engrosan cuando cruzan el valor de Simpson 40-60 J m 


\section{Blanco Cape}

Summer. The three transects crossed this front in different locations and at different stages of the season (Fig. 1), which will bring differences to the comparison. In January 2001, the critical Simpson parameter was crossed twice around 48 and $46.7^{\circ} \mathrm{S}$, delimiting the homogeneous side of the Blanco Cape front. Temperature showed a minimum $\left(\sim 10.8^{\circ} \mathrm{C}\right.$, approximately $3^{\circ} \mathrm{C}$ difference with the outer side of the front, Fig. 2), while nutrients were high ( $~ 7$ and $1.5 \mu \mathrm{M}$ for nitrate and silicate, respectively, Fig. 3a, c). However, it should be noted that the transect path between these latitudes was close to the historical critical Simpson-50 isopleth, so the observations may represent the frontal zone rather than well mixed waters. Phosphate was also high (Fig. 3b), but it had two maximum values close to the frontal zone. Chlorophyll- $a$ showed a maximum of $1.90 \mu \mathrm{g} \mathrm{L}^{-1}$ within the homogeneous side (Fig. 3d).

The March 2002 transect was similar to that of January 2001 at this latitude, although even closer to the critical Simpson line. Moreover, March is the end of the austral summer and the warm season at Blanco Cape is shorter than at Valdés Peninsula. The thermal signal of the tidal front is not as clear in 2002 as in 2001 . Notwithstanding, nitrate shows an abrupt increase (up to $8.4 \mu \mathrm{M}$ ), indicating the presence of the front. Silicate and phosphate also has higher values within the front (2.8 and $0.9 \mu \mathrm{M}$ respectively), although these increases were not as abrupt as in nitrate. The chl- $a$ peak $\left(4.15 \mu \mathrm{g} \mathrm{L}^{-1}\right)$ was found in stratified waters north of the front and the nutrient maxima.

In February 2003, the temperatures reached a minimum of $11.9^{\circ} \mathrm{C}\left(\Delta \mathrm{T} \sim 1.7^{\circ} \mathrm{C}\right)$, although there was a relative maximum in the middle of the well mixed region $\left(13.1^{\circ} \mathrm{C}\right)$. This pattern was reproduced inversely by nitrate, ranging between 1.2 and $2.5 \mu \mathrm{M}$. Phosphate and silicate also presented this shape, with maximum values up to 0.8 and $2.7 \mu \mathrm{M}$ and relative minima of 0.7 and 1.8 $\mu \mathrm{M}$ respectively. Chlorophyll- $a$ had a similar 2-peaks pattern, and the southern maximum $\left(3.13 \mu \mathrm{g} \mathrm{L}^{-1}\right)$ was located very close to the frontal zone. The northern maximum extended for $\sim 2^{\circ}$ of latitude, from within the homogeneous to the stratified side of the front in the north. The high values in the well mixed region were mainly due to the presence of large diatoms, while the peaks towards the stratified sides of the front were associated to blooms of flagellates $\leq 5 \mu \mathrm{m}$ (Fig.5). Nitrate seemed to be the limiting nutrient in the region, as identified by Charpy-Roubaud et al. (1983). Furthermore, there was a significant correlation $\left(\mathrm{R}^{2}=0.7 ; P<0.05\right)$ between chl- $a$ and nitrate along the three studied years.
Fall. In both April 2002 and May 2003 there was no clear thermal signals of the Blanco Cape front because the ocean was already cooling and stratification was weaker. Nonetheless, at $\sim 46^{\circ} \mathrm{S}$ where the northern edge of the front was observed during summer, both transects showed a local temperature decrease $\left(0.4\right.$ and $0.3^{\circ} \mathrm{C}$ for 2002 and 2003, respectively) (Fig. 2d; 2e). These features can be interpreted as a remaining of the summer front, whose shape had changed due to the weakening of stratification.

In 2003, the local temperature dropped at $46^{\circ} \mathrm{S}$. It appears together with a peak in nutrients $(7.6,0.8$, and 4.4 $\mu \mathrm{M}$ for nitrate, phosphate, and silicate), which reinforces the idea of the presence of a weak front. A small and well defined chl- $a$ maximum $\left(1.71 \mu \mathrm{g} \mathrm{L}^{-1}\right)$ was observed to the north of the nutrient peak, which was associated with high dinoflagellates densities (data not shown). To the south, chl- $a$ concentrations decreased slightly and were relatively uniform $\left(\sim 1.17 \mu \mathrm{g} \mathrm{L}^{-1}\right)$. In 2002, the temperature decrease was also accompanied by high nutrients, though there were no clear peaks as in 2003. Chl- $a$ does not presented sharp variations at these latitudes, although there was a relative maximum of 1.02

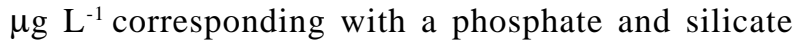
minima.

\section{South of $50^{\circ} \mathrm{S}$}

Summer. Although the three transects showed a gradual decrease of temperature with increasing latitude (Fig. 2a, b, c), they all presented a change in the temperature slope around $51^{\circ} \mathrm{S}$. In 2001 there was a more abrupt decrease $\left(\sim 1^{\circ} \mathrm{C}\right.$ ) between $\sim 51$ and $52^{\circ} \mathrm{S}$, and temperatures remained approximately constant south of $53^{\circ} \mathrm{S}\left(\sim 8.3^{\circ} \mathrm{C}\right)$. This transect crossed the critical Simpson line almost perpendicularly. In 2002 there was a temperature change of $\sim 1^{\circ} \mathrm{C}$ not only at $51^{\circ} \mathrm{S}$, but also around $50^{\circ} \mathrm{S}$, because the transect was close to the critical Simpson line at that latitude. South of $52^{\circ} \mathrm{S}$ the temperature continued evenly. Something similar occurred in 2003. This transect presented a second temperature drop around $52^{\circ} \mathrm{S}$ when crossing the front. South of $51^{\circ} \mathrm{S}$, temperature was approximately stable around $9.7^{\circ} \mathrm{C}$.

In the three transects, these temperature decreases were accompanied by large nitrate increases (up to 13.1, 15.9, and $7.2 \mu \mathrm{M}$ for 2001, 2002, and 2003 respectively) (Fig. 3a). Nutrient concentrations observed in this region are possibly due to subantarctic origin.

In terms of phosphate and silicate (Fig. 3b, c), 2001 and 2002 transects also showed increases, although not as notorious as in nitrate (phosphate up to 1.9 and 1.1 $\mu \mathrm{M}$ and silicate up to 3 and $4.4 \mu \mathrm{M}$ in 2001 and 2002, respectively). Phosphate in the 2003 transect showed a 


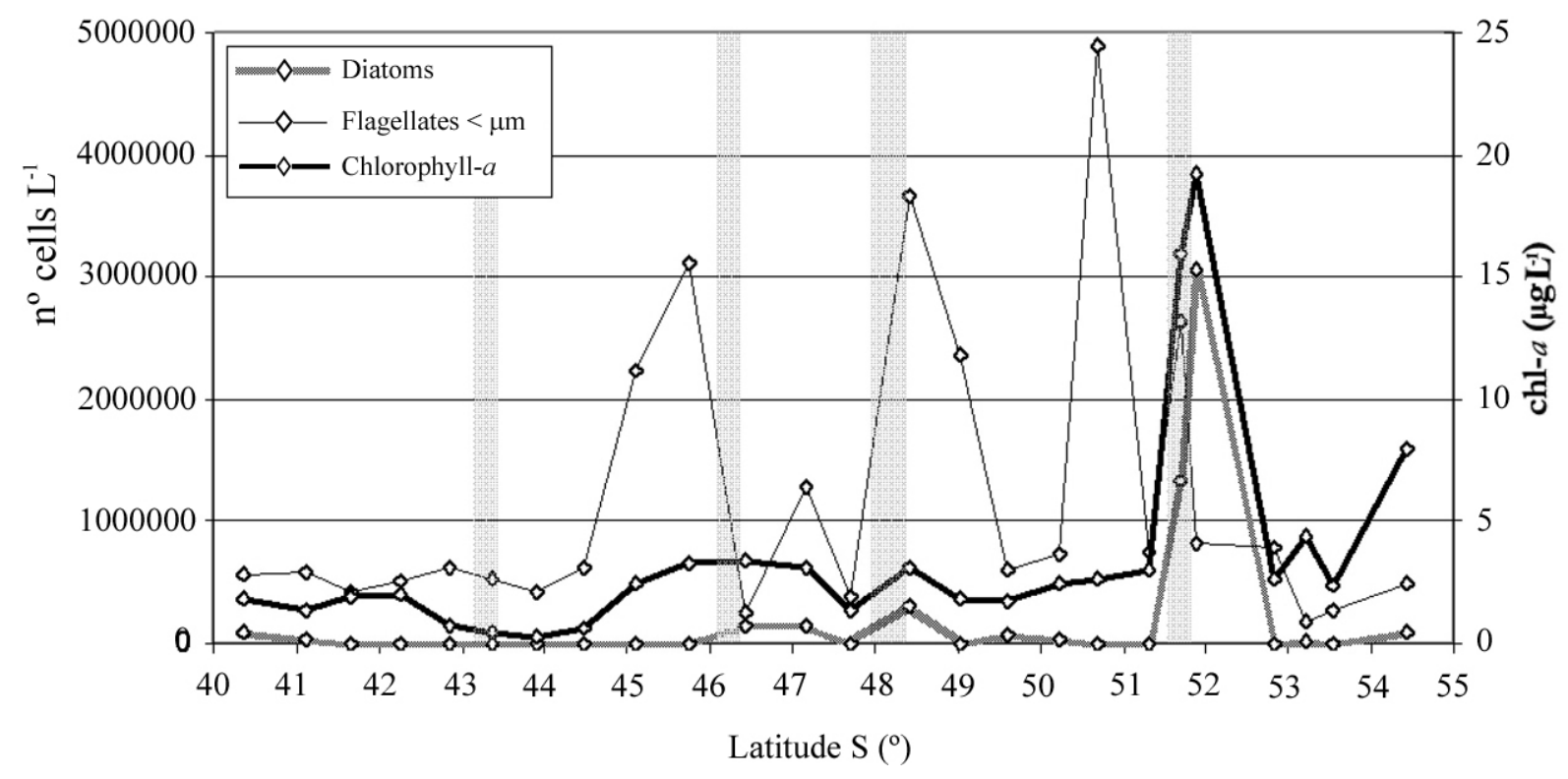

Figure 5

\begin{abstract}
Diatoms, flagellates $(\leq 5 \mu \mathrm{m})$ and chl- $a$ concentrations for summer 2003. Shaded regions represent the frontal zone as the area where the Simpson parameter was around $20 \%$ of the critical value (around $40-60 \mathrm{~J} \mathrm{~m}^{-3}$ )
\end{abstract}

Diatomeas, flagelados $(\leq 5 \mu \mathrm{m})$ y concentración de clorofila- $a$ durante el verano de 2003. Las regiones sombreadas representan la zona frontal así como el área donde el parámetro de Simpson fue cercano al 20\% del valor crítico (40-60 J m³)

similar pattern as nitrate south of $50^{\circ} \mathrm{S}$, between 0.4 and $0.8 \mu \mathrm{M}$. Silicate showed a peak of $1.5 \mu \mathrm{M}$ around $53^{\circ} \mathrm{S}$ and a minor maximum around $50^{\circ} \mathrm{S}(0.8 \mu \mathrm{M})$. The high chl- $a$ concentration observed in February 2003 in the homogeneous side of the front explains the lower nutrient values measured in this transect (Fig. 3d). In this sense, concentrations were always above $2.00 \mu \mathrm{g} \mathrm{L}^{-1}$ and reached up to $19.22 \mu \mathrm{g} . \mathrm{L}^{-1}$ at $\sim 52^{\circ} \mathrm{S}$. Moreover, the chl- $a$ maxima at $\sim 52^{\circ} \mathrm{S}$ and $54.5^{\circ} \mathrm{S}$ corresponded to large-size diatom blooms ( $3 \times 10^{6}$ and $10^{5}$ cells $\mathrm{L}^{-1}$ respectively, see Fig. 5), leading to the observed silicate depletion.

A relative maximum chl- $a$ in $2001\left(4.06 \mu \mathrm{g} \mathrm{L}^{-1}\right)$ was found in the homogeneous side of the front. The 2002 transect had uniformly low chl- $a\left(<1.00 \mu \mathrm{g} \mathrm{L}^{-1}\right)$. A significant correlation $\left(\mathrm{R}^{2}=0.33 ; P<0.05\right)$ between chl$a$ and nitrate was found in this zone.

Fall. South of $50^{\circ} \mathrm{S}$, temperature dropped $\sim 2^{\circ} \mathrm{C}$ and $1.1^{\circ} \mathrm{C}$ in 2002 and 2003, respectively (Figs. 2d,e) coincident with an increase in nitrate (Fig. 4a). This may indicate the presence of a moderate front during fall, between warm waters north of $50^{\circ} \mathrm{S}$ and cold and well mixed waters to the south, as it was previously suggested by Bianucci (2004). Nitrate minima at $\sim 50^{\circ} \mathrm{S}$ (8.8 and 7.8 $\mu \mathrm{M}$ ) were still much higher than concentrations observed in summer transects (4.2 $\mu \mathrm{M}$ in March 2002 and close to zero in February 2003), implying less consumption and or more pumping of nutrients.

A slight local rise in phosphate also followed nitrate increments (Fig. 4b). Silicate, as phosphate, was high overall in the region south of $50^{\circ} \mathrm{S}$ (maximum up to 3.9 and $3.6 \mu \mathrm{M}$ in 2002 and 2003 respectively) (Fig. 4c), although it did not follow exactly the same pattern as nitrate or phosphate.

Chl- $a$ was low in both years $\left(<1 \mu \mathrm{g} \mathrm{L}^{-1}\right)$ and quite uniform (variations with latitude were only up to $0.3 \mu \mathrm{g}$ $\mathrm{L}^{-1}$ ) (Fig. 4d).

\section{Discussion and conclusions}

The five alongshore transects analyzed in this work showed localized temperature decreases (Fig. 2), usually given along with increases in nutrients (Figs. 3 and 4). It was possible to associate these features to the presence of tidal fronts because of the combination of these data with the location of the critical Simpson-50 parameter presented by Bianchi et al. (2005). Despite of the different data set used to compute this parameter, there is a good correspondence between front location and the features mentioned above (temperature gradient, as well as nutrient variations). Moreover, tidal fronts depend tightly on bathymetry (Simpson \& Hunter 1974), so it is 
reasonable to expect that the location of the fronts in the present data set will match the critical Simpson isopleths.

The surface temperature/nutrient distributions across tidal fronts can be explained by the following mechanism: vertical mixing occurring in the shallower side of the front brings bottom nutrients up to the upper layers, while surface temperature is reduced by mixing with colder deeper waters. Moreover, the instability of the water column in this mixing zone does not provide an adequate environment for most primary producers (which need a stable upper layer to stay in the euphotic zone), so reduction or lack of consumption would also allow elevated nutrient concentrations. This has been confirmed by primary production measurements performed during the same cruises (Schloss et al. 2007). Nitrate and chl-a distribution had significant negative correlations at both the Blanco Cape and the $50^{\circ} \mathrm{S}$ fronts in summer, but not in fall, further supporting those results. Nitrate and temperature had inverse patterns, but phosphate and silicate sometimes did not follow the same trend. In summer, nitrate was almost undetectable in stratified waters outside frontal regions (except in March 2002 south of $49^{\circ} \mathrm{S}$, where cooling had started, weakening the southern front). Hence, nitrate seems to be a limiting nutrient in these stratified waters, leading to high phosphate and silicate concentrations. This idea is supported by N:P ratios lower than Redfield values in $99 \%$ of the sampled stations.

It is difficult to compare our results to previous studies due to the absence of cruises similar to the ones presented here and the variation of nutrient concentrations along the year. Brandhorst \& Castello (1971) showed nitrate and phosphate concentrations for years 1959-1970. In spite of the temporal distance and logistical differences, our summer results coincide with theirs on magnitude and tendency. From a regional perspective, Esteves \& Varela (1991) showed values similar to ours for nitrate, phosphate, and chl- $a$ in Valdés Peninsula open sea during summer and fall. Carreto et al. (1986) described the distribution of temperature, nitrate, and chl- $a$ at the Valdés Peninsula front during spring. In a recent work, Carreto et al. (2007) analyze the frontal systems of the Argentinean Continental Shelf, including the tidal fronts. This entire works support the regional processes exposed here.

Dogliotti et al. (2009) showed that chl- $a$ distributions are usually displaced from the nutrients maxima and located in the stratified side of the front. However, the latter was not always the case (e.g. summer chl- $a$ maximum south of $51^{\circ} \mathrm{S}$ or in Blanco Cape front). The available phytoplanktonic data for 2003 showed that high chl- $a$ in well mixed regions corresponded to diatoms, while peaks in stratified areas were due to small flagellates $(\leq 5 \mu \mathrm{m})$ (Fig. 4). Diatoms had already been observed in the homogeneous side of tidal fronts (Carreto et al. 1986, Carreto et al. 2007), as well as in other well-mixed environments (Carreto et al. 2003, Lutz et al. 2006). In the present data set this phytoplanktonic group was positively correlated with chl- $a$ concentration (in summer: $\mathrm{r}=0.91, P<0.0001$ ), implying that it was best represented in biomass estimations. However, small flagellates dominated the phytoplanktonic composition along both 2003 transects (except in summer around $52^{\circ} \mathrm{S}$ ) and represented over $70 \%$ of the total phytoplankton abundance. Schloss et al. (2007) emphasizes that recycling of nutrients and carbon on the Patagonian shelf is enhanced in small flagellates communities. Future work will need to focus on nano and picophytoplankton to assess their role in the regional planktonic community structure.

In fall, high nutrient concentrations and weaker front signals were observed at latitudes higher than $44^{\circ} \mathrm{S}$ (Blanco Cape and front South of $50^{\circ} \mathrm{S}$ ), while fronts were still apparent at lower latitudes (Valdés Peninsula). This responds to the progressive northwards erosion of the seasonal thermocline in this season and the consequent disruption of stratification.

In addition to the frontal signals in nutrients, there was a south-north overall reduction of nitrate along the PCSA. This may be explained by the origin of the waters in this region, which are the subantarctic waters, flowing from the northern limit of the Drake Passage onto the Patagonian shelf (Piola \& Rivas 1997, Guerrero \& Piola 1997). These waters get into the shelf between Malvinas Islands and Tierra del Fuego (the southernmost province of Argentina), and they are modified by the Magellan Strait outflow around $53^{\circ} \mathrm{S}$. As these nutrient-rich waters flow north (driven by strong Westerlies), nutrients are consumed and also mixed other water masses (see Guerrero \& Piola 1997 or Bianchi et al. 2005 for a review on PCSA water masses). This could explain the background south-north gradient observed in nitrate. Contrasting with these trends, phosphate and silicate do not follow a similar gradient. Local nutrient sources from rivers and eolian dust might explain these results. Gaiero et al. (2004) showed that the Andean mountains are the only water source for Patagonian Rivers. Although large sediment yields are generated in the Andes, a significant portion of the particulate load carried by the major rivers is retained in proglacial lakes, and little reaches the coast. Moreover, the three rivers with largest mean discharge (Colorado, Negro, and Santa Cruz Rivers, with discharges up to $858 \mathrm{~m}^{3} \mathrm{~s}^{-1}$ ) have low mean nitrate concentration 
(Depetris et al. 2005). All other Patagonian rivers have mean discharges below $42 \mathrm{~m}^{3} \mathrm{~s}^{-1}$ (Gaiero et al. 2002) and do not affect significantly the ocean water masses. Hence, nitrate concentrations described in this work are not expected to show river signals and the background gradient can be linked mainly to the origin of the water masses. However, Patagonian rivers transport phosphate concentrations comparable to those observed in the ocean (Depetris et al. 2005), so that it is not possible to rule out riverine influence in the coastal data presented here. In this sence, terrestrial input could explain the lack of a north-south phosphate gradient. No silicate data were found to carry out a similar comparison. Patagonian topsoil was identified as a contributor to the eolian dust delivered to the ocean, so westerly winds could transport dust-associated nutrients to the sea ( $\mathrm{Li}$ et al. 2008). The direct effect of these sources in the macronutrient concentration is poorly known.

The present work provides an updated biogeochemical description of this Large Marine Ecosystem, emphasizing the tight connection between physics and biology in the region. More studies focusing on the three dimensional distribution of nutrients will be necessary to better understand this austral system and to provide a sound basis for their future preservation.

\section{Acknowledgments}

This study was conducted within the framework of a cooperative research program (ARGAU, Programme de Coopération avec la ARGentine pour l'étude de l'océan Atlantique AUstral) between the Laboratoire de Biogéochimie et Chimie Marines at the Université Pierre et Marie Curie in Paris (France), the Instituto Antártico Argentino and the Servicio de Hidrografía Naval (Argentina) from 2001 to 2004. We wish to thank L. Cantoni, A. Ulrich, and technical personnel from the Servicio de Hidrografía Naval for assistance during fieldwork, as well as crew members of the Almirante Irizar and personnel of Laboratorio de Oceanografía Química y Contaminación de Aguas of the Centro Nacional Patagónico. This project benefited from the PEI2001, CONICET, and PICTO 6524/1108/03-ANPCyT 01-11563 grants to I.R.S.

\section{Literature cited}

Acha EM, HW Mianzan, RA Guerrero, M Favero \& J Bava. 2004. Marine fronts at the continental shelves of austral South America. Physical and ecological processes. Journal of Marine Systems 44: 83-105.

Almandoz G. 2008. Distribución geográfica y variación interanual del género Pseudo-nitzschia (Bacillariophyceae) en aguas del la Plataforma del Mar Argentino y Antártida. Tesis Doctoral, Universidad Nacional de La Plata, La Plata, 148 pp.
Almandoz GO, MF Ferrario, GA Ferreyra, IR Schloss, JL Esteves \& FE Paparazzo. 2007. The genus Pseudonitzschia (Bacillariophyceae) in continental shelf waters of Argentina (Southwestern Atlantic Ocean, 38-55²). Harmful Algae 6: 93-103.

Aranciaga I. 2003. Mapa pesquero patagónico austral. Hacia una demanda de ciencia y tecnología en el desarrollo del sector. Cuadernos de Ciencia y Tecnología 20: 123-160.

Balestrini CF, AR Poisson, GA Ferreyra, MF Ferrario, B Schauer, IR Schloss, DA Molina, H Sala, AA Bianchi, D Ruiz-Pino, AR Piola \& M Sarraceno. 2000. Project 'Argau': Preliminary data-report. Direccion Nacional del Antártico. Contribución 529: 1-29.

Berrow SD, AG Wood \& PA Prince. 2000. Foraging location and range of White-chinned Petrels Procellaria aequinoctialis breeding in the South Atlantic. Journal of Avian Biology 31: 303-311.

Bianchi AA, L Bianucci, AR Piola, D Ruiz-Pino, I Schloss, A Poisson \& C Balestrini. 2005. Vertical stratification and air-sea $\mathrm{CO}_{2}$ fluxes in the Patagonian shelf. Journal of Geophysical Research 110(C7): 1-10.

Bianucci L. 2004. Climatología de los frentes de marea en la Plataforma Continental y su rol en los flujos mar-atmósfera de $\mathrm{CO}_{2}$. Seminario de Licenciatura en Ciencias Biológicas, FCEN, Universidad de Buenos Aires, Argentina, 83 pp.

Bisbal GA. 1995. The Southeast South American shelf large marine ecosystem. Evolution and components. Marine Policy 19: 21-38.

Bogazzi E, A Baldoni, AL Rivas, P Martos, R Reta, JM Orensanz, M Lasta, P Dell'arciprete \& F Werner. 2005. Spatial correspondence between areas of concentration of Patagonian scallop (Zygochlamys patagonica) and frontal systems in the southwestern Atlantic. Fisheries Oceanography 14(5): 359-376.

Brandhorst W \& JP Castello. 1971. Evaluación de los recursos de anchoíta (Engraulis anchoita) frente a la Argentina y Uruguay. I. Las condiciones oceanográficas, sinopsis del conocimiento actual sobre la anchoíta y el plan para su evaluación. Contribuciones del Instituto De Biología Marina, Mar del Plata, Argentina 166: 1-63.

Carreto JI, HR Benavides, RM Negri \& PD Glorioso. 1986. Toxic red-tide in the Argentine Sea. Phytoplankton distribution and survival of the toxic dinoflagellate Gonyaulax excavata in a frontal area. Journal of Plankton Research 8(1): 15-28.

Carreto JI, NG Montoya, HR Benavides, RA Guerrero \& MO Carignan. 2003. Characterization of spring phytoplankton communities in the Río de La Plata maritime front using pigment signatures and cell microscopy. Marine Biology 143(5): 1013-1027.

Carreto JI, MO Carignan, NG Montoya \& AD CucchiColleoni. 2007. Ecología del fitoplancton en los sistemas frontales del Mar Argentino. In: Carreto JI \& C Bremec (eds). El mar argentino y sus recursos pesqueros 5: 11-13. INIDEP, Mar del Plata. 
Charpy-Roubaud CJ, LJ Charpy \& SY Maestrini. 1983. Nutrient enrichments of waters of "Golfo de San José" (Argentina, 42 oS), growth and species selection of phytoplankton. Marine Ecology 4(1): 1-18.

Croxall JP \& AG Wood. 2002. The importance of the Patagonian Shelf for the top predator species breeding at South Georgia. Aquatic Conservation. Marine and Freshwater Ecosystems 12: 101-118.

Depetris PJ, DM Gaiero, JL Probst, J Hartmann \& S Kempe. 2005. Biogeochemical output and typology of rivers draining Patagonia's Atlantic seaboard. Journal of Coastal Research 21(4): 835-844.

Dogliotti AI, IR Schloss, G Almandoz \& DA Gagliardini. 2009. Evaluation of SeaWiFS and MODIS chlorophyll- $a$ products in the Argentinean Patagonian Continental Shelf $\left(38^{\circ} \mathrm{S}-55^{\circ} \mathrm{S}\right)$. International Journal of Remote Sensing 30(1): 251-273.

Esteves JL \& DE Varela. 1991. Dynamics of nutrient cycling of the Valdes Bay-Punta Cero pond system (Peninsula Valdes, Patagonia) Argentine. Oceanologica Acta 14(1): 5158 .

Flint MV, IN Sukhanova, AI Kopylov, SG Poyarkov \& TE Whitledge. 2002. Plankton distribution associated with frontal zones in the vicinity of the Pribilof Islands. DeepSea Research II 49: 6069-6093.

Gaiero PM, JL Probst, PJ Depetris, L Leleyter \& S Kempe. 2002. Riverine transfer of heavy metals from Patagonia to the southwestern Atlantic Ocean. Regional Environmental Change 3(1-3): 51-64.

Gaiero PM, PJ Depetris, JL Probst, SM Bidart \& L Leleyter. 2004. The signature of river- and wind-borne materials exported from Patagonia to the southern latitudes: a view from REEs and implications for paleoclimatic interpretations. Earth and Planetary Science Letters 219(34): 357-376.

Glorioso PD. 2002. Modelling the South West Atlantic. Aquatic Conservation. Marine and Freshwater Ecosystems 12: 2737.

Glorioso PD \& RA Flather. 1997. The Patagonian Shelf tides, Progress in Oceanography 40(1/4): 263-283.

Guerrero RA \& AR Piola. 1997. Masas de agua en la Plataforma Continental. In: Boschi E (ed). El mar argentino y sus recursos pesqueros 1: 107-118. INIDEP, Mar del Plata.

Hansen JE, P Martos \& A Madirolas. 2001. Relationship between spatial distribution of the Patagonian stock of Argentine anchovy, Engraulis anchoita, and sea temperatures during late spring to early summer. Fisheries Oceanography 10(2): 193-206.

Joiris CR. 1996. At-sea distribution of seabirds and marine mammals around Svalbard, summer 1991. Polar Biology 16: 423-429.
Koen-Alonso M, EA Crespo, SN Pedraza, NA Garcia \& MA Coscarella. 2000. Food habits of the South American sea lion, Otaria flavescens, of Patagonia, Argentina. Fishery Bulletin 98: 250-263.

Koen-Alonso M, EA Crespo, NA Garcia, SN Pedraza, PA Mariotti, B Beron-Vera \& NJ Mora. 2001. Food habits of Dipturus chilensis (Pisces: Rajidae) off Patagonia, Argentina. Journal of Marine Science 58: 288-297.

Li F, P Ginoux \& V Ramaswamy. 2008. Distribution, transport, and deposition of mineral dust in the Southern Ocean and Antarctica: Contribution of major sources, Journal of Geophysical Research 113, D10207. <doi:10.1029/2007JD009190>

Lutz VA, A Subramaniam, RM Negri, RI Silva \& JI Carreto. 2006. Annual variations in bio-optical properties at the 'Estación Permanente de Estudios Ambientales (EPEA)' coastal station, Argentina. Continental Shelf Research 26(10): 1093-1112.

Palma ED, RP Matano, AR Piola \& LE Sitz. 2004. A comparison of the circulation patterns over the Southwestern Atlantic Shelf driven by different wind stress climatologies, Geophysical Research Letters 31, L24303. <doi:10.1029/2004GL021068>

Paparazzo FE. 2003. Evolución de nutrientes inorgánicos en aguas oceánicas y su relación con la biomasa fitoplanctónica. Seminario de Licenciatura en Ciencias Biológicas, Universidad Nacional de la Patagonia San Juan Bosco, Puerto Madryn, 90 pp.

Piola AR \& AL Rivas. 1997. Corrientes en la plataforma continental. In: Boschi E (ed). El mar argentino y sus recursos pesqueros 1: 119-132. INIDEP, Mar del Plata.

Rivas A. 1997. Current-meter observations in the Argentine Continental Shelf. Continental Shelf Research 17(4): 391406.

Rivas A. 2006. Quantitative estimation of the influence of surface thermal fronts over chlorophyll concentration at the Patagonian shelf. Journal of Marine Systems 63: 183190.

Rivas AL, AI Dogliotti \& DA Gagliardini. 2006. Seasonal variability in satellite-measured surface chlorophyll in the Patagonian Shelf. Continental Shelf Research 26(6): 703720.

Romero SI, AR Piola, M Charo \& CAE Garcia. 2006 Chlorophyll- $a$ variability off Patagonia based on SeaWiFS data, Journal of Geophysical Research 111, C05021 <doi:10.1029/2005JC003244>

Sabatini M \& P Martos. 2002. Mesozooplancton features in a frontal area off northern Patagonia (Argentina) during Spring 1995 and 1998. Scientia Marina 66(3): 215-232.

Sabatini M, R Reta \& R Matano. 2004. Circulation and zooplankton biomass distribution over the southern Patagonian shelf during late summer. Continental Shelf Research 24: 1359-1373. 
Schloss IR, GA Ferreyra, ME Ferrario, GO Almandoz, R Codina, AA Bianchi, CF Balestrini, HA Ochoa, D RuizPino \& A Poisson. 2007. Role of plankton communities in $\mathrm{pCO}_{2}$ sea-air variation in the southwestern Atlantic Ocean. Marine Ecology Progress Series 332: 93-106.

Simpson JH. 1981. The shelf-sea fronts: Implications of their existence and behaviour. Philosophical Transactions of the Royal Society A 302: 531-546.

Simpson JH \& JR Hunter. 1974. Fronts in the Irish Sea. Nature 250: 404-406 <doi:10.1038/250404a0>

Sponaugle S, RK Cowen, A Shanks, SG Morgan, JM Leis, J Pineda, GW Boehlert, MJ Kingsford, KC Lindeman,
C Grimes, JL Munro. 2002. Predicting self-recruitment in marine populations: Biophysical correlates and mechanisms. Bulletin of Marine Science 24: 341-356.

Strickland JDH \& TR Parsons. 1972. A practical handbook of seawater analysis. Fisheries Researches Board of Canadá, Bulletin 167: 1-310.

Utermöhl H. 1958. Zur vervollkommnung der quantitativen phytoplankton-methodik. Mitteilungen. Internationale Vereinigung für Theoretische und Angewandte Limnologie 9: 1-38.

Veit RR. 1995. Pelagic communities of seabirds in the South Atlantic Ocean. IBIS 137: 1-10.

Recibido el 01 de julio de 2009 y aceptado el 28 de diciembre de 2009 